\title{
Catalogue of Polar Bear (Ursus maritimus) Maternal Den Locations in the Beaufort Sea and Neighboring Regions, Alaska, 1910-2010
}

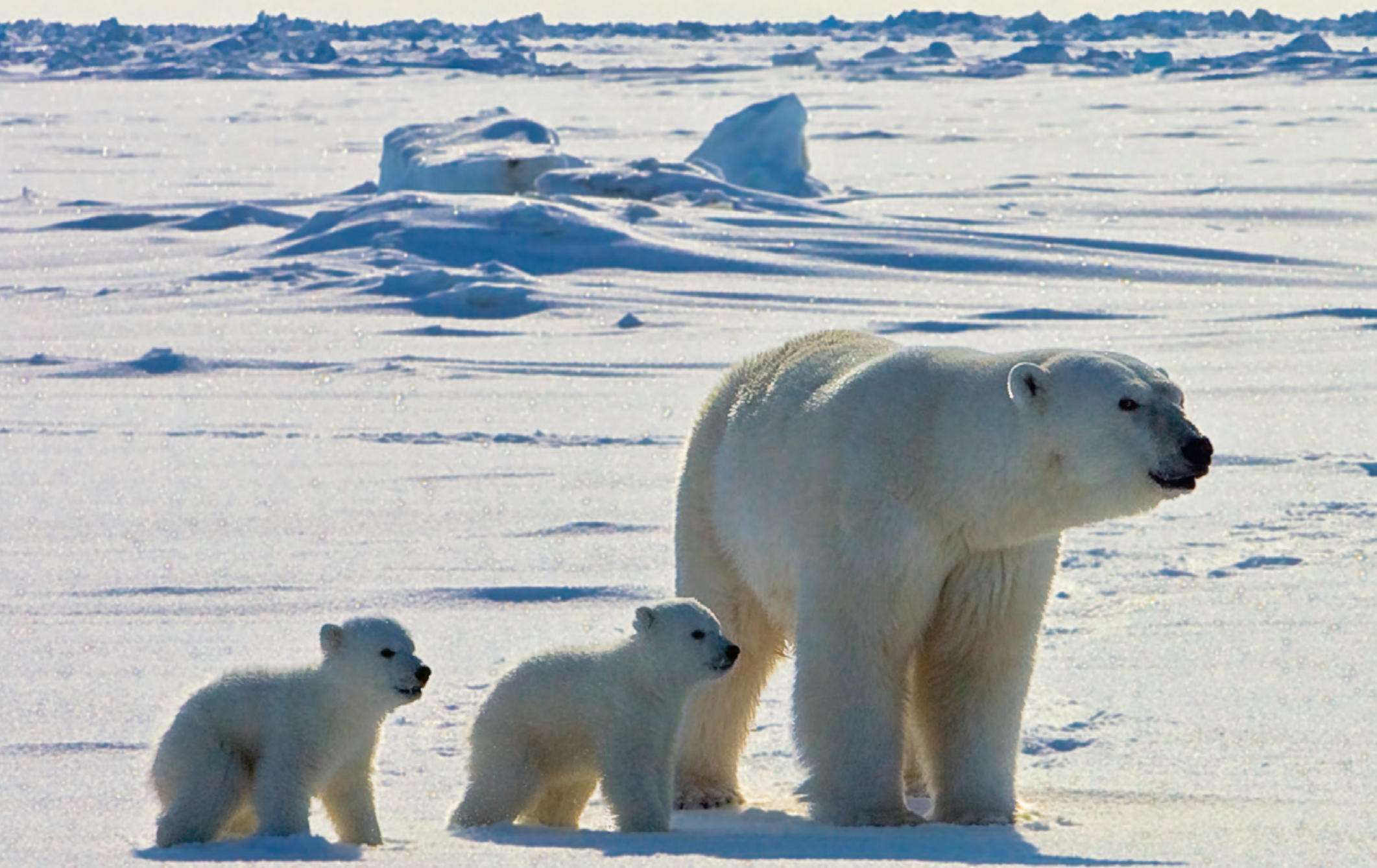

Data Series 568

U.S. Department of the Interior

U.S. Geological Survey 
Cover: An adult female polar bear and her two cubs travel across the sea ice of the Arctic Ocean north of the Alaska coast, April, 2008. (Photograph by Mike Lockhart, U.S. Geological Survey.) 


\section{Catalogue of Polar Bear (Ursus maritimus) Maternal Den Locations in the Beaufort Sea and Neighboring Regions, Alaska, 1910-2010}

By George M. Durner, Anthony S. Fischbach, Steven C. Amstrup, and David C. Douglas

Data Series 568 


\title{
U.S. Department of the Interior \\ KEN SALAZAR, Secretary
}

\section{U.S. Geological Survey \\ Marcia K. McNutt, Director}

\section{U.S. Geological Survey, Reston, Virginia: 2010}

\author{
For more information on the USGS — the Federal source for science about the Earth, its natural and living resources, \\ natural hazards, and the environment, visit http://www.usgs.gov or call 1-888-ASK-USGS \\ For an overview of USGS information products, including maps, imagery, and publications, \\ visit http://www.usgs.gov/pubprod \\ To order this and other USGS information products, visit http://store.usgs.gov
}

Any use of trade, product, or firm names is for descriptive purposes only and does not imply endorsement by the U.S. Government.

Although this report is in the public domain, permission must be secured from the individual copyright owners to reproduce any copyrighted materials contained within this report.

Suggested citation:

Durner, G.M., Fischbach, A.S., Amstrup, S.C., and Douglas, D.C., 2010, Catalogue of polar bear (Ursus maritimus) maternal den locations in the Beaufort Sea and neighboring regions, Alaska, 1910-2010: U.S. Geological Survey Data Series 568, $14 \mathrm{p}$. 


\section{Contents}

Abstract
Introduction...
Methods of Discovery
Distribution of Den Locations
Summary
Acknowledgments
References Cited
Appendix 1. Records of Polar Bear Maternal Dens Collected by the USGS, Alaska
Science Center

\section{Figures}

Figure 1. Photograph showing a female polar bear as she emerges from her maternal den adjacent to a coastal bank on Foggy Island, near Prudhoe Bay, Alaska, April 2009

Figure 2. Maps showing distribution of polar bear maternal dens encountered through satellite telemetry, VHF telemetry, reported by others, and during polar bear capture operations on sea ice and nearshore areas, and surveys with ForwardLooking Infrared (FLIR) of terrestrial denning habitat, Beaufort Sea and neighboring regions, Alaska, 1910-2010

Figure 3. Maps showing distribution of polar bear maternal dens discovered by VHF telemetry during 1981-91 when most data were collected through systematic surveys, and after 1991 when VHF telemetry missions only occurred near shore, Beaufort Sea and neighboring regions, Alaska

\section{Conversion Factors and Datum}

Conversion Factors

\begin{tabular}{|c|c|c|}
\hline Multiply & By & To obtain \\
\hline meter (m) & 3.281 & foot (ft) \\
\hline kilometer (km) & 0.6214 & mile (mi) \\
\hline
\end{tabular}

Datum

Horizontal coordinate information is referenced to the World Geographic Datum 1984. 
This page intentionally left blank. 


\title{
Catalogue of Polar Bear (Ursus maritimus) Maternal Den Locations in the Beaufort Sea and Neighboring Regions, Alaska, 1910-2010
}

\author{
By George M. Durner, Anthony S. Fischbach, Steven C. Amstrup, and David C. Douglas
}

\begin{abstract}
This report presents data on the approximate locations and methods of discovery of 392 polar bear (Ursus maritimus) maternal dens found in the Beaufort Sea and neighboring regions between 1910 and 2010 that are archived by the U.S. Geological Survey, Alaska Science Center, Anchorage, Alaska. A description of data collection methods, biases associated with collection method, primary time periods, and spatial resolution are provided. Polar bears in the Beaufort Sea and nearby regions den on both the sea ice and on land. Standardized VHF surveys and satellite radio telemetry data provide a general understanding of where polar bears have denned in this region over the past 3 decades. Den observations made during other research activities and anecdotal reports from other government agencies, coastal residents, and industry personnel also are reported. Data on past polar bear maternal den locations are provided to inform the public and to provide information for natural resource agencies in planning activities to avoid or minimize interference with polar bear maternity dens.
\end{abstract}

\section{Introduction}

Polar bear (Ursus maritimus) research has been ongoing in Alaska since 1967. Research was initiated to address management issues including sport and subsistence hunting, and the establishment and expected growth of the petroleum industry in Alaska and neighboring Canada. Research has focused on developing indexes of population size and trend and identifying major aspects of life history that are strong determinants of those trends. Polar bears require dens of snow and ice that remain undisturbed throughout den tenure for the successful parturition and early development of neonates.
Suitable denning habitat generally occurs on the leeward side of terrestrial banks and bluffs, or sea ice pressure ridges, where drifting snow can accumulate (Durner and others, 2003; fig. 1). Given this requirement, the timing and distribution of maternal denning were considered important information for management decisions on the conservation of polar bears.

This report meets the information needs of natural resource agencies in their efforts to minimize interactions between human activities and polar bear maternal dens. The data are derived from a mix of reported information, nonstandardized and standardized surveys, and satellite telemetry records of polar bear maternal dens in the Beaufort Sea and neighboring regions between 1910 and 2010.

\section{Methods of Discovery}

Data in this report span a century of observations by local residents, visitors to the Arctic, industry personnel, and natural resources agents of Borough, State and Federal governments. Between 1965 and 1972, polar bear research and management was under the jurisdiction of the Alaska Department of Fish and Game (ADFG). The Marine Mammal Protection Act (MMPA) of 1972 resulted in the transfer of all polar bear research and management to separate divisions of the U.S. Fish and Wildlife Service (USFWS). In 1993, most Department of the Interior (DOI) biological research was moved into the National Biological Survey (later renamed the National Biological Service). Another transfer of DOI research occurred in 1996 when these duties became the responsibility of USGS Biological Resources Division (Wagner, 1999). Because these different agencies housed a continuation of the same research program, they are collectively referred to in this report as the Alaska Science Center (ASC). The ASC is presently the curator of polar bear maternal den records for the U.S. Department of the Interior. 


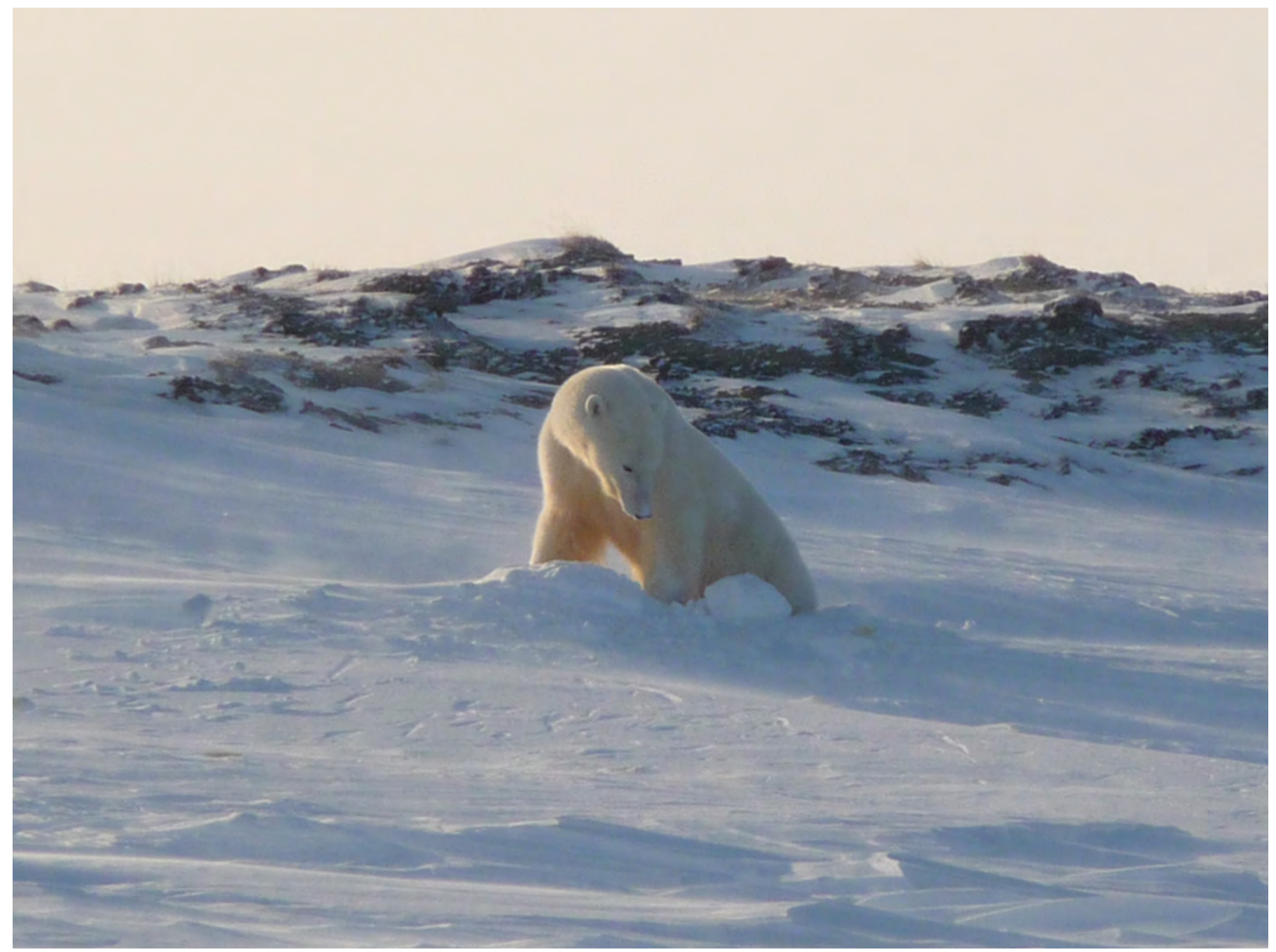

Figure 1. A female polar bear as she emerges from her maternal den adjacent to a coastal bank on Foggy Island, near Prudhoe Bay, Alaska, April 2009. (Photograph by Rusty Robinson, Brigham Young University, Provo.)

Prior to 1980 , much data on polar bear maternal dens in the Beaufort Sea and neighboring regions were collected through observations by coastal residents, guides of polar bear hunters, and through interviews with industry personnel (Lentfer and Hensel, 1980). Additional observations were made during autumn fixed-wing aircraft surveys of nearshore habitats by the ADFG $(1965,1967,1971)$, the USFWS (1973, 1974, 1976), and by the USFWS during March and April (1973, 1974, 1975; Lentfer and Hensel, 1980). Opportunistic observations of maternal dens were recorded during spring (March and April) mark-recapture research (Lentfer, 1975; Lentfer and others, 1980) in northwestern and northern Alaska by the ADFG (1967-72) and the USFWS (1974-76).
From 1980 through 1994, capture-mark-recapture efforts were intensified to estimate the population size of polar bears in the southern Beaufort Sea (Amstrup and others, 1986, 2001). These efforts involved 4-6 weeks of fieldwork each spring and 4-5 weeks during some autumns. In 1981, radio tracking began after the development of very high frequency (VHF) radio transmitter collars that were suitable for deployment on adult female polar bears. In 1985, the ASC deployed the first successful satellite-linked radio transmitters (Platform Transmitter Terminal, or PTT) on polar bears.

Between 1985 and 1994, VHF and PTT units provided data on polar bear movements, distribution, habitat use, and maternal denning. 
Beaufort Sea-wide standardized VHF surveys were conducted by aircraft four times each winter during 1983-87, and twice each winter during 1988-91. A primary goal of these surveys was to collect data on the distribution of polar bear maternal dens (Amstrup and Gardner, 1994). Following 1985, location and sensor data from PTTs deployed on female polar bears in the Beaufort and Chukchi Seas (Garner and others, 1990) enabled the remote identification of maternal dens (Amstrup and Gardner, 1994; Fischbach and others, 2007). The ASC also continued to record observations reported by Borough, State, and Federal agencies, local residents, industry personnel, and other groups and individuals. Maternal dens were also observed and recorded by ASC personnel incidental to standard searches for polar bears during nearshore capturerecapture and radio-collaring efforts. The development of VHF radio tags combined with standardized high-altitude radio-tracking surveys of the Beaufort Sea and the deployment of PTTs provided data of maternal dens that was largely free from geographic biases inherent in other types of observations. Data resulting from these tracking methods allowed the ASC to develop a better understanding of the distribution and timing of polar bear maternal denning in Alaska and neighboring regions.

Following a hiatus in data collection that began in 1995, the ASC resumed polar bear field research in autumn 1997 (Regehr and others, 2006). Spring and autumn field research were conducted until 2001, after which the late-autumn ice formation that became typical prevented autumn captures. Between 1997 and 2010, the ASC continued to deploy PTTs and some VHF radio tags. Recent assessments of the distribution of maternal denning have been performed entirely with PTT data (Fischbach and others, 2007). Additional data have been collected through restricted VHF telemetry surveys over the nearshore Alaska Beaufort Sea, experimental surveys with Forward-Looking Infrared (FLIR; Amstrup and others, 2004) over likely polar bear denning habitat (Durner and others, 2003), and reports from local residents, industry personnel, and visitors to northern Alaska.

Because of the diversity of data sources and the substrate choice of polar bears (sea ice, fast ice, or land) the spatial resolution of the den location data varies. Many reported observations were recorded to the nearest minute of latitude and longitude because they were estimated from a hunter's memory of where a den was observed many years prior. Conventional, FLIR, VHF tracking, and PTT tag relocation observations were usually recorded to the nearest tenth to hundredths of latitude and longitude minute. Additionally, satellite observation location quality was dependent on signal quality. Most PTT locations, however, were $\pm 1.7 \mathrm{~km}$ of the true location of the animal (Fancy and others, 1988).

Because sea ice continually drifts (with the exception of nearshore fast ice), sea ice den locations are reported for a single point of the den tenure (generally the den entrance period, if available) and do not reflect the movement of the den during a winter of ice drift. Only measures of terrestrial or fast ice den sites visited on the ground or recorded near ground level from an aircraft with a Global Positioning System (GPS) receiver are within $100 \mathrm{~m}$ of the true location of the den.

Follow-up visits to dens, either by low-level aircraft reconnaissance or on-ground measures by personnel, resulted in improved estimates of den locations. For example, many dens discovered by satellite telemetry during early winter were surveyed with aerial VHF telemetry in late winter. The VHF telemetry location would supersede the previous satellite telemetry-derived location. Likewise, dens may have been visited on the ground following their discovery by satellite telemetry or VHF telemetry. Because ground-visits were the most precise mode of location determination, these superseded prior locations derived from either telemetry method. This process often resulted in minor changes of the recorded den location as new data became available. The records provided in this report are the best current estimate of a den location as of 2010. Subsequent observations of recently discovered dens (that is, during the year of this report) may refine those location estimates.

Field descriptors for each data record (see appendix 1) include the ASC assigned den identification number (DenId), the year that cubs would have emerged from the den (Spring year), the data source (Data_Source), encounter method (Discovery_method), and location in decimal degrees (latitude and longitude). Field observations made prior to 1995 were recorded in North American Datum 1927 and post-projected as World Geographic Datum 1984. All Argos observations and field observations made after 1994 were recorded in World Geographic Datum 1984. The data provided here are maternal den locations, where "maternal den" represents a structure that was used by a pregnant bear to give birth to young and, should parturition be successful, continue to be used as shelter for developing neonates during late winter and early spring in the year following parturition. Whether a structure was a maternal den was determined by assessing the timing and duration of den tenure, assessment of temperature, activity and signal quality from PTTs, direct observations of females with neonates, visual inspection of the den following departure of the family, and visual inspection of the ground following snow melt. The USGS den data base also includes records of temporary dens not used for parturition, autumn exploratory dens that were apparently deemed unsuitable by the bear, FLIR hotspots that later showed no evidence of being a maternal den, and erroneous or questionable reports from other parties. These other records, which showed no compelling evidence that they were maternal dens, are not provided in this report. Because these other observations are excluded from this report, the reader will note gaps in consecutive DenID records in appendix 1. 


\section{Distribution of Den Locations}

As of spring 2010, a total of 392 records of polar bear maternal dens had been collected by the ASC (appendix 1). This database included observations reported by other individuals or institutions (Discovery_method = REPORT, $\mathrm{n}=69$ ), observations from polar bear field research (Discovery_method $=$ CONVENTIONAL, $\mathrm{n}=40$ ), dens encountered by FLIR surveys (Discovery_method = FLIR, $\mathrm{n}=13$ ), dens located by VHF telemetry relocations (Discovery_method $=$ VHF_RADIO, $\mathrm{n}=101$ ), and dens discovered by satellite radio telemetry (Discovery_method $=$ SATELLITE, $\mathrm{n}=169$ ). All VHF telemetry records were collected between 1982 and 2009, satellite records between
1986 and 2010, and FLIR records between 1999 and 2007. CONVENTIONAL observations were made between 1969 and 2010. REPORT observations were made between 1910 and 2007.

The encounter (discovery) method strongly influenced the observed distribution of den locations. SATELLITE and VHF RADIO observations were distributed throughout the Beaufort and Chukchi Seas (igss. $2 A$ and $2 B$ ). REPORT, FLIR, and CONVENTIONAL observations, however, occurred mostly near shore and on land (figs. $2 C$ and $\underline{2 D}$ ). The distribution of dens discovered by VHF telemetry also was dependent on the time period that the data were collected. Whereas VHF telemetry data collected between 1983 and 1991 were through systematic Beaufort Sea-wide surveys (Amstrup and Gardner, 1994), VHF telemetry missions after this period were restricted to nearshore regions (fig. 3).
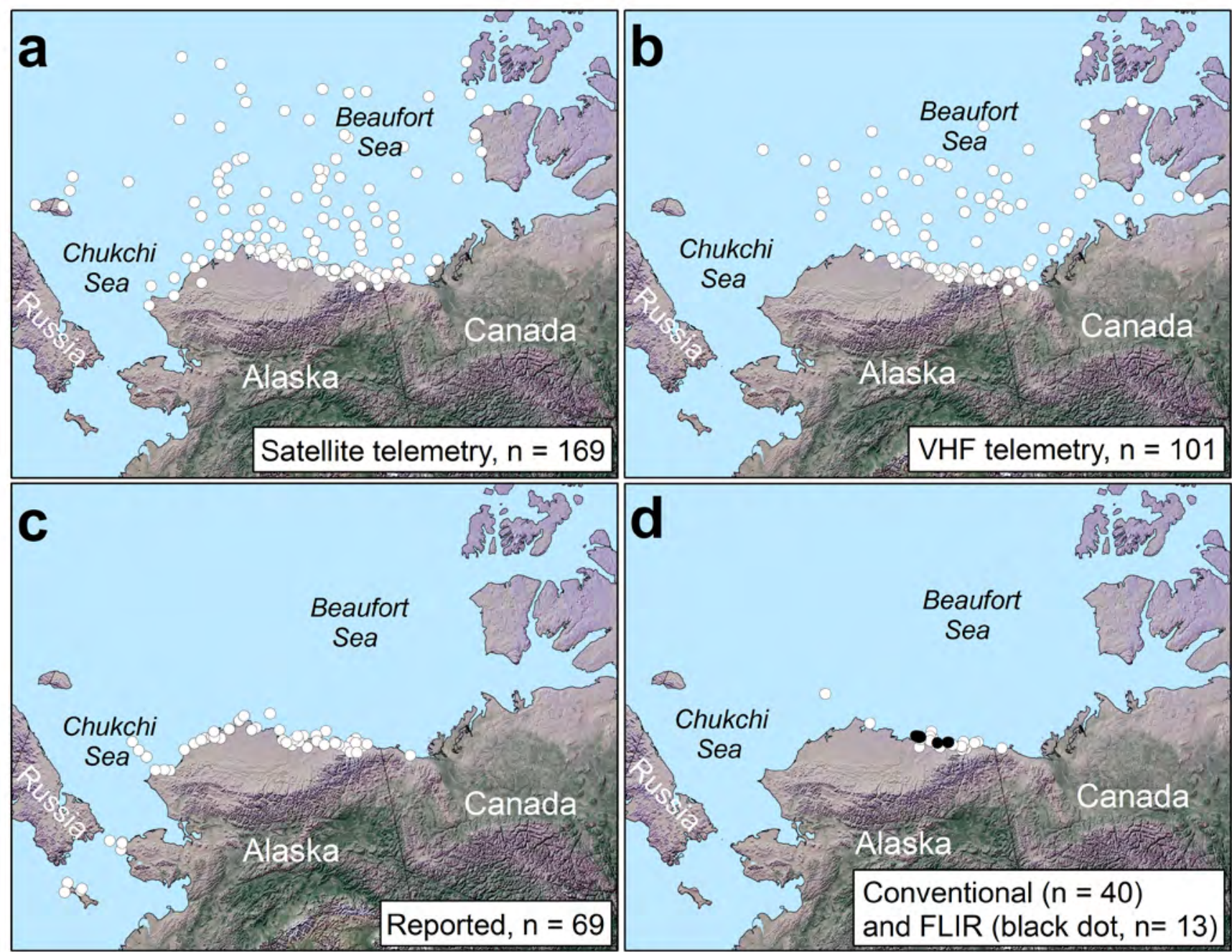

Figure 2. Distribution of polar bear maternal dens encountered through: $(A)$ satellite telemetry, $(B)$ VHF telemetry, $(C)$ reported by others, and $(D)$ during polar bear capture operations on sea ice and nearshore areas, and surveys with Forward-Looking Infrared (FLIR) of terrestrial denning habitat, Beaufort Sea and neighboring regions, Alaska, 1910-2010. 

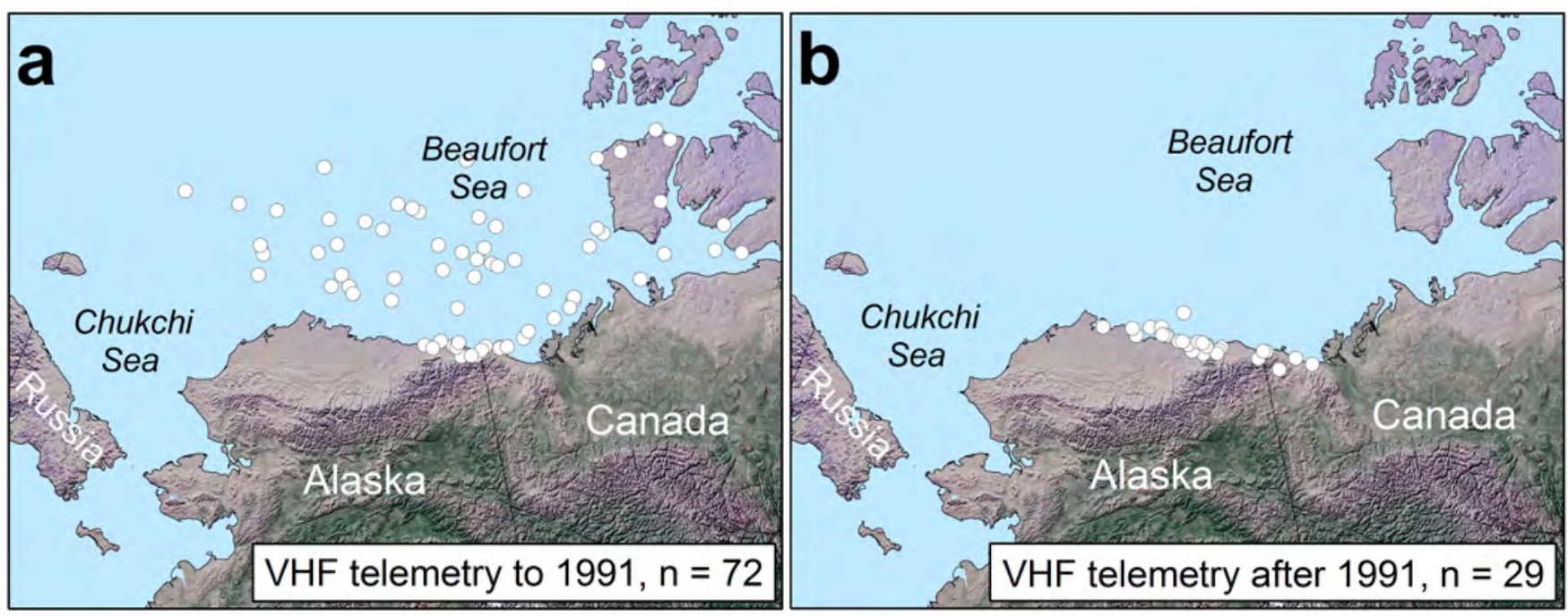

Figure 3. Distribution of polar bear maternal dens discovered by VHF telemetry $(A)$ during 1981-91 when most data were collected through systematic surveys, and $(B)$ after 1991 when VHF telemetry missions only occurred near shore, Beaufort Sea and neighboring regions, Alaska.

\section{Summary}

Records of maternal den locations in the Beaufort Sea and neighboring regions maintained by the U.S. Geological Survey, Alaska Science Center are provided to the public. Users are cautioned that observations of maternal dens are dependent on the method of data collection; thus, certain methods may provide a better representation of den distribution than others.

\section{Acknowledgments}

The authors recognize the contributions of Gerald Garner (ASC, deceased) who deployed satellite collars on female polar bears in the Chukchi Sea between 1987 and 1994. We also recognize the contributions of numerous local residents and industry personnel whose observations added to the data in this report. Primary funding for this work was provided by the USGS. Additional support was provided by the USFWS, British Petroleum Exploration - Alaska, ConocoPhillips Alaska, ExxonMobil, Polar Bears International, the World Wildlife Fund, and prior to 1973, the State of Alaska. We appreciate the constructive suggestions by Gail Irvine (ASC), Karen Oakley (ASC), John Pearce (ASC), and Evan Richardson (Environment Canada) on earlier versions of this data report.

\section{References Cited}

Amstrup, S.C., and Gardner, C., 1994, Polar bear maternity denning in the Beaufort Sea: Journal of Wildlife Management, v. 58, no. 1, p. 1-10.

Amstrup, S.C., McDonald, T.L., and Stirling, I., 2001 Polar bears in the Beaufort Sea: A 30-year mark-recapture case history: Journal of Agricultural, Biological, and Environmental Statistics, v. 6, , no. 2, p. 221-234.

Amstrup, S.C., Stirling, I., and Lentfer. J.W., 1986, Past and present status of polar bears in Alaska: Wildlife Society Bulletin, v. 14, no. 3, p. 241-254.

Amstrup, S.C., York, G., McDonald, T.L., Nielson, R., and Simac, K., 2004, Detecting denning polar bears with Forward-Looking Infrared (FLIR) imagery: Bioscience, v. 54 , no. 4 , p. $337-344$.

Durner, G.M., Amstrup, S.C., and Fischbach, A.S., 2003, Habitat characteristics of polar bear terrestrial maternal den sites in northern Alaska: Arctic, v. 56, no. 1, p. 55-62.

Fancy, S.G., Pank, L.F., Douglas, D.C., Curby, C.H., Garner, G.W., Amstrup, S.C., and Regelin, W.L., 1988, Satellite telemetry: a new tool for wildlife research and management: U.S. Fish and Wildlife Service Resource Publication 172, $55 \mathrm{p}$. 
Fischbach, A.S., Amstrup, S.C., and Douglas, D.C., 2007, Landward and eastward shift of Alaskan polar bear denning associated with recent sea ice changes: Polar Biology, v. 30, no. 11, p. 1395-1405 [doi:10.1007/s00300-007-0300-4].

Garner, G.W., Knick, S.T., and Douglas, D.C., 1990, Seasonal movements of adult female polar bears in the Bering and Chukchi Seas, in Darling, L.M., and Archibald, W.R., eds., Bears-Their Biology and Management: Proceedings of the 8th International Conference on Bear Research and Management, Victoria, B.C., February 20-25, 1989, International Association for Bear Research and Management, Washington, D.C. p. 219-226.

Lentfer, J.W., 1975, Polar bear denning on drifting sea ice: Journal of Mammalogy, v. 56, p. 716-718.
Lentfer, J.W., and Hensel, R.J., 1980, Alaskan polar bear denning: International Conference on Bear Research and Management, v. 3, p. 101-108.

Lentfer, J.W., Hensel, R.J., Gilbert, J.R., and Sorensen, F.E., 1980, Population characteristics of Alaskan polar bears: International Conference on Bear Research and Management, v. 3, p. 109-115.

Regehr, E.V., Amstrup, S.C., and Stirling, Ian, 2006, Polar bear population status in the southern Beaufort Sea: U.S. Geological Survey Open-File Report 2006-1337, 20 p.

Wagner, F.H., 1999, Whatever happened to the National Biological Survey? BioScience, v. 49, no. 3, p. 219-222. 


\section{Appendix 1. Records of Polar Bear Maternal Dens Collected by the USGS, Alaska Science Center}

[See appendix 2 for a definition of Data_source and Discovery_method codes]

\begin{tabular}{|c|c|c|c|c|c|c|}
\hline Record & DenID & Spring_year & Data_source & Discovery_method & Latitude & Longitude \\
\hline 1 & 126 & 1910 & ASC & REPORT & 70.0833 & -149.1667 \\
\hline 3 & 128 & 1913 & ASC & REPORT & 70.1667 & -147.3333 \\
\hline 5 & 179 & 1935 & $\mathrm{ASC}$ & REPORT & 70.9167 & -155.0000 \\
\hline 6 & 132 & 1951 & ASC & REPORT & 70.1667 & -143.6667 \\
\hline 7 & 177 & 1955 & MMM & REPORT & 63.7500 & -171.7333 \\
\hline 10 & 237 & 1957 & MMM & REPORT & 70.4470 & -159.0408 \\
\hline 11 & 134 & 1958 & ASC & REPORT & 70.5333 & -149.8667 \\
\hline 12 & 216 & 1965 & MMM & REPORT & 70.3100 & -160.9900 \\
\hline 13 & 135 & 1967 & $\mathrm{ASC}$ & REPORT & 70.5000 & -148.0000 \\
\hline 14 & 136 & 1968 & ASC & REPORT & 71.5000 & -153.3333 \\
\hline 15 & 137 & 1969 & ASC & CONVENTIONAL & 69.8330 & -144.1333 \\
\hline 20 & 141 & 1972 & $\mathrm{ASC}$ & REPORT & 69.5000 & -168.0000 \\
\hline 21 & 142 & 1972 & ASC & REPORT & 69.8333 & -143.0000 \\
\hline 22 & 143 & 1973 & ASC & CONVENTIONAL & 70.1000 & -149.3333 \\
\hline 23 & 144 & 1973 & ASC & CONVENTIONAL & 70.1854 & -146.0610 \\
\hline 24 & 189 & 1973 & MMM & REPORT & 70.3300 & -150.0800 \\
\hline 25 & 147 & 1974 & ASC & CONVENTIONAL & 72.2000 & -160.5833 \\
\hline 26 & 148 & 1974 & ASC & CONVENTIONAL & 69.9333 & -144.4667 \\
\hline 27 & 150 & 1974 & ASC & CONVENTIONAL & 69.8167 & -144.5833 \\
\hline 28 & 718 & 1974 & ASC & CONVENTIONAL & 69.9333 & -144.4667 \\
\hline 29 & 152 & 1975 & ASC & CONVENTIONAL & 70.4000 & -147.6667 \\
\hline 30 & 153 & 1975 & ASC & REPORT & 70.1833 & -143.6667 \\
\hline 31 & 154 & 1975 & ASC & REPORT & 70.2000 & -143.5833 \\
\hline 41 & 161 & 1981 & ASC & CONVENTIONAL & 70.5540 & -149.4476 \\
\hline 42 & 162 & 1982 & ASC & CONVENTIONAL & 70.0265 & -142.6845 \\
\hline 43 & 163 & 1982 & MMM & REPORT & 65.5000 & -167.6667 \\
\hline 44 & 186 & 1982 & INDUSTRY & REPORT & 68.9333 & -164.2333 \\
\hline 45 & 540 & 1982 & ASC & CONVENTIONAL & 70.1180 & -144.2670 \\
\hline 46 & 622 & 1982 & ASC & VHF_RADIO & 69.5335 & -141.4071 \\
\hline 47 & 165 & 1983 & INDUSTRY & REPŌRT & 69.6500 & -143.6667 \\
\hline 48 & 178 & 1983 & MMM & REPORT & 71.1667 & -157.0333 \\
\hline 49 & 181 & 1983 & MMM & REPORT & 70.1333 & -162.0000 \\
\hline 50 & 202 & 1983 & MMM & REPORT & 65.7760 & -167.7120 \\
\hline 51 & 533 & 1983 & ASC & VHF_RADIO & 71.1000 & -142.2500 \\
\hline 52 & 702 & 1983 & ASC & VHF_RADIO & 69.5833 & -138.8500 \\
\hline 53 & 166 & 1984 & ADFG & REPŌRT & 68.9167 & -164.8333 \\
\hline 54 & 507 & 1984 & ASC & VHF_RADIO & 72.8000 & -138.5167 \\
\hline 55 & 513 & 1984 & ASC & VHF_RADIO & 72.5000 & -139.5000 \\
\hline
\end{tabular}


Appendix 1. Records of polar bear maternal dens collected by the USGS, Alaska Science Center-Continued

[See appendix 2 for a definition of Data_source and Discovery_method codes]

\begin{tabular}{|c|c|c|c|c|c|c|}
\hline Record & DenID & Spring_year & Data_source & Discovery_method & Latitude & Longitude \\
\hline 56 & 516 & 1984 & $\mathrm{ASC}$ & VHF_RADIO & 74.1833 & -150.3833 \\
\hline 58 & 518 & 1984 & $\mathrm{ASC}$ & $\mathrm{VHF}^{-}$RADIO & 73.3667 & -136.8500 \\
\hline 60 & 529 & 1984 & ASC & VHF_RADIO & 72.5000 & -153.0000 \\
\hline 61 & 539 & 1984 & ASC & VHF_RADIO & 69.9524 & -143.1785 \\
\hline 62 & 544 & 1984 & ASC & VHF_RADIO & 69.7500 & -140.4000 \\
\hline 65 & 549 & 1984 & ASC & VHF_RADIO & 71.0000 & -134.0833 \\
\hline 66 & 626 & 1984 & ASC & VHF_RADIO & 73.1667 & -143.0000 \\
\hline 67 & 628 & 1984 & ASC & VHF_RADIO & 74.6667 & -146.6667 \\
\hline 68 & 630 & 1984 & ASC & VHF_RADIO & 74.2167 & -117.3000 \\
\hline 69 & 633 & 1984 & $\mathrm{ASC}$ & VHF_RADIO & 77.0333 & -119.1333 \\
\hline 70 & 704 & 1984 & ASC & VHF_RADIO & 70.4000 & -131.8167 \\
\hline 75 & 556 & 1985 & ASC & VHF_RADIO & 74.6333 & -170.2333 \\
\hline 76 & 557 & 1985 & $\mathrm{ASC}$ & VHF_RADIO & 73.8000 & -138.3333 \\
\hline 77 & 560 & 1985 & ASC & VHF_RADIO & 72.1333 & -137.6667 \\
\hline 78 & 564 & 1985 & ASC & VHF RADIO & 70.0995 & -145.6740 \\
\hline 79 & 565 & 1985 & ASC & VHF_RADIO & 74.3000 & -154.3000 \\
\hline 80 & 583 & 1985 & ASC & CONVENTIONAL & 69.6000 & -140.1500 \\
\hline 81 & 629 & 1985 & $\mathrm{ASC}$ & VHF_RADIO & 69.6667 & -140.8333 \\
\hline 82 & 631 & 1985 & ASC & VHF_RADIO & 74.4833 & -145.1667 \\
\hline 83 & 167 & 1986 & MMM & REPŌRT & 63.3667 & -171.7500 \\
\hline 84 & 168 & 1986 & INDUSTRY & REPORT & 70.3000 & -148.0000 \\
\hline 85 & 501 & 1986 & ASC & SATELLITE & 72.0500 & -152.0500 \\
\hline 86 & 503 & 1986 & ASC & SATELLITE & 70.0000 & -138.8333 \\
\hline 87 & 511 & 1986 & ASC & VHF RADIO & 70.0226 & -142.7237 \\
\hline 96 & 569 & 1986 & ASC & VHF_RADIO & 76.0000 & -154.9000 \\
\hline 97 & 571 & 1986 & ASC & VHF_RADIO & 72.3833 & -161.2000 \\
\hline 98 & 573 & 1986 & $\mathrm{ASC}$ & VHF_RADIO & 71.9000 & -151.9667 \\
\hline 99 & 576 & 1986 & ASC & SATELLITE & 73.4833 & -153.8333 \\
\hline 100 & 578 & 1986 & $\mathrm{ASC}$ & VHF RADIO & 75.7000 & -138.1667 \\
\hline 101 & 579 & 1986 & ASC & VHF_RADIO & 71.6167 & -148.3000 \\
\hline 102 & 580 & 1986 & ASC & SATELLITE & 71.6000 & -157.1667 \\
\hline 103 & 582 & 1986 & ASC & VHF_RADIO & 72.1500 & -154.0500 \\
\hline 104 & 584 & 1986 & ASC & VHF_RADIO & 74.2333 & -132.9333 \\
\hline 105 & 619 & 1986 & ASC & VHF_RADIO & 74.1667 & -121.7500 \\
\hline 106 & 620 & 1986 & ASC & VHF_RADIO & 69.9667 & -118.4167 \\
\hline 107 & 621 & 1986 & $\mathrm{ASC}$ & VHF_RADIO & 69.4667 & -116.5833 \\
\hline 108 & 623 & 1986 & ASC & SATELLITE & 71.3667 & -142.4500 \\
\hline 109 & 632 & 1986 & $\mathrm{ASC}$ & VHF_RADIO & 72.0500 & -126.9500 \\
\hline 110 & 634 & 1986 & $\mathrm{ASC}$ & VHF_RADIO & 71.8333 & -128.6667 \\
\hline 111 & 635 & 1986 & ASC & VHF_RADIO & 73.7000 & -116.5833 \\
\hline 112 & 636 & 1986 & ASC & VHF RADIO & 70.2500 & -125.5000 \\
\hline 113 & 637 & 1986 & ASC & VHF_RADIO & 72.1500 & -120.5833 \\
\hline 114 & 638 & 1986 & ASC & VHF_RADIO & 72.3667 & -143.0000 \\
\hline 115 & 639 & 1986 & ASC & VHF_RADIO & 70.5000 & -131.6667 \\
\hline
\end{tabular}


Appendix 1. Records of polar bear maternal dens collected by the USGS, Alaska Science Center-Continued

[See appendix 2 for a definition of Data_source and Discovery_method codes]

\begin{tabular}{|c|c|c|c|c|c|c|}
\hline Record & DenID & Spring_year & Data_source & Discovery_method & Latitude & Longitude \\
\hline 116 & 640 & 1986 & $\mathrm{ASC}$ & VHF_RADIO & 72.2667 & -127.2833 \\
\hline 118 & 644 & 1986 & ASC & VHF_RADIO & 69.9000 & -136.4333 \\
\hline 120 & 646 & 1986 & $\mathrm{ASC}$ & VHF_RADIO & 70.5000 & -116.5833 \\
\hline 121 & 647 & 1986 & ASC & VHF_RADIO & 70.6333 & -122.5833 \\
\hline 122 & 648 & 1986 & ASC & VHF_RADIO & 74.3167 & -124.3333 \\
\hline 125 & 502 & 1987 & ASC & SATELLITE & 73.5333 & -147.0500 \\
\hline 126 & 504 & 1987 & ASC & VHF_RADIO & 69.6333 & -139.1167 \\
\hline 127 & 524 & 1987 & ASC & VHF_RADIO & 69.6000 & -139.2333 \\
\hline 128 & 526 & 1987 & ASC & SATELLITE & 69.7167 & -134.4333 \\
\hline 129 & 530 & 1987 & ASC & VHF_RADIO & 69.9775 & -145.0028 \\
\hline 130 & 535 & 1987 & $\mathrm{ASC}$ & SATELLITE & 69.5280 & -141.0346 \\
\hline 135 & 642 & 1987 & ASC & SATELLITE & 74.6167 & -143.9333 \\
\hline 136 & 130 & 1988 & MMM & REPORT & 65.8000 & -167.7000 \\
\hline 137 & 170 & 1988 & ASC & CONVENTIONAL & 69.9629 & -144.5608 \\
\hline 138 & 174 & 1988 & ASC & CONVENTIONAL & 70.1787 & -145.9653 \\
\hline 139 & 203 & 1988 & MMM & REPORT & 65.7680 & -167.7060 \\
\hline 140 & 505 & 1988 & ASC & SATELLITE & 69.9590 & -144.5803 \\
\hline 141 & 514 & 1988 & ASC & SATELLITE & 72.7167 & -159.1167 \\
\hline 142 & 542 & 1988 & $\mathrm{ASC}$ & SATELLITE & 76.1000 & -160.7500 \\
\hline 143 & 575 & 1988 & ASC & SATELLITE & 72.3333 & -161.9167 \\
\hline 144 & 577 & 1988 & ASC & SATELLITE & 77.2333 & -157.0167 \\
\hline 145 & 588 & 1988 & ASC & SATELLITE & 70.0668 & -143.9921 \\
\hline 146 & 592 & 1988 & $\mathrm{ASC}$ & SATELLITE & 76.1833 & -166.9833 \\
\hline 147 & 593 & 1988 & ASC & SATELLITE & 70.5500 & -150.3667 \\
\hline 156 & 548 & 1989 & ASC & SATELLITE & 74.7667 & -157.7833 \\
\hline 157 & 550 & 1989 & ASC & SATELLITE & 71.8667 & -138.0333 \\
\hline 158 & 558 & 1989 & $\mathrm{ASC}$ & SATELLITE & 71.7500 & -148.6333 \\
\hline 159 & 568 & 1989 & ASC & SATELLITE & 69.6167 & -139.0090 \\
\hline 160 & 586 & 1989 & $\mathrm{ASC}$ & SATELLITE & 72.2540 & -152.8650 \\
\hline 161 & 589 & 1989 & ASC & SATELLITE & 71.8000 & -140.1667 \\
\hline 162 & 594 & 1989 & $\mathrm{ASC}$ & SATELLITE & 70.8000 & -138.3667 \\
\hline 163 & 597 & 1989 & ASC & SATELLITE & 69.4667 & -139.7000 \\
\hline 164 & 600 & 1989 & ASC & SATELLITE & 71.1333 & -152.8000 \\
\hline 165 & 602 & 1989 & ASC & SATELLITE & 70.0129 & -143.0345 \\
\hline 166 & 605 & 1989 & ASC & SATELLITE & 70.8333 & -154.0333 \\
\hline 167 & 643 & 1989 & ASC & SATELLITE & 73.8833 & -146.3500 \\
\hline 168 & 848 & 1989 & ASC & SATELLITE & 71.2717 & -158.5300 \\
\hline 169 & 850 & 1989 & ASC & SATELLITE & 70.5908 & -163.0000 \\
\hline 170 & 851 & 1989 & ASC & SATELLITE & 74.1410 & -160.2367 \\
\hline 171 & 200 & 1990 & MMM & REPORT & 65.7600 & -168.8970 \\
\hline 172 & 522 & 1990 & ASC & VHF RADIO & 70.2333 & -132.3000 \\
\hline 173 & 532 & 1990 & ASC & SATELLITE & 69.9741 & -144.7728 \\
\hline 174 & 537 & 1990 & ASC & SATELLITE & 69.5500 & -139.6333 \\
\hline 175 & 552 & 1990 & ASC & SATELLITE & 71.2333 & -160.5167 \\
\hline
\end{tabular}


Appendix 1. Records of polar bear maternal dens collected by the USGS, Alaska Science Center-Continued

[See appendix 2 for a definition of Data_source and Discovery_method codes]

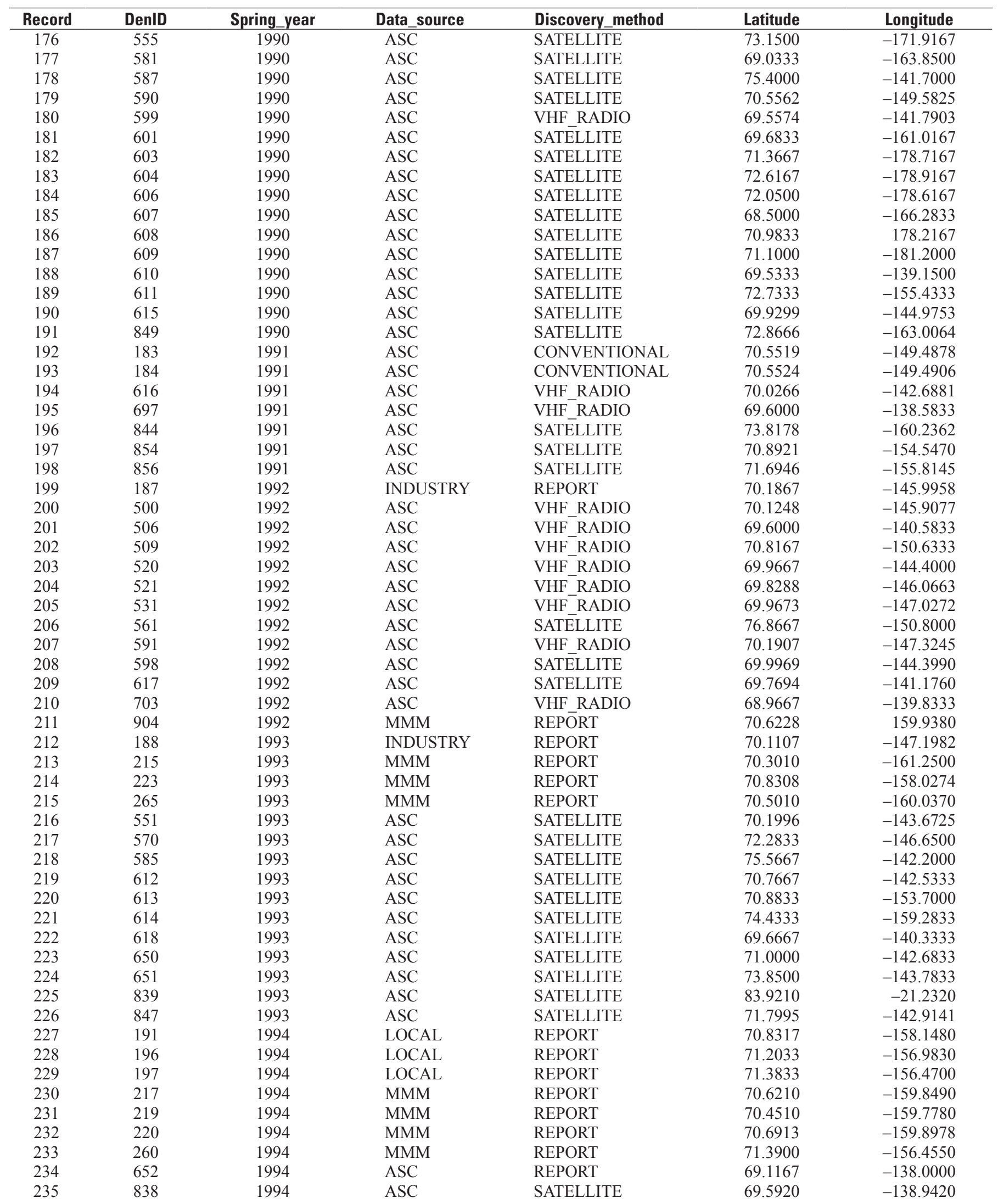


Appendix 1. Records of polar bear maternal dens collected by the USGS, Alaska Science Center-Continued

[See appendix 2 for a definition of Data_source and Discovery_method codes]

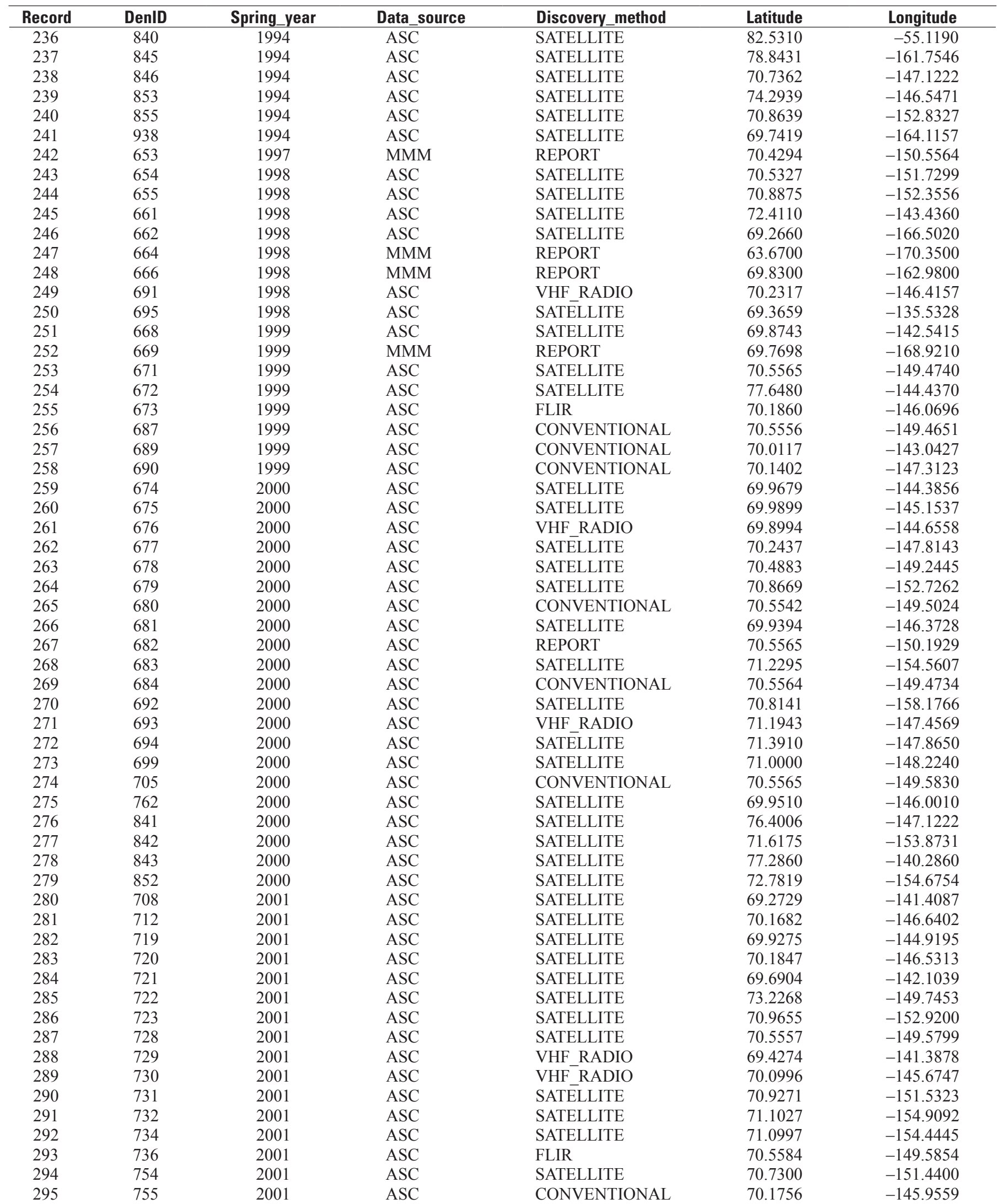


Appendix 1. Records of polar bear maternal dens collected by the USGS, Alaska Science Center-Continued

[See appendix 2 for a definition of Data_source and Discovery_method codes]

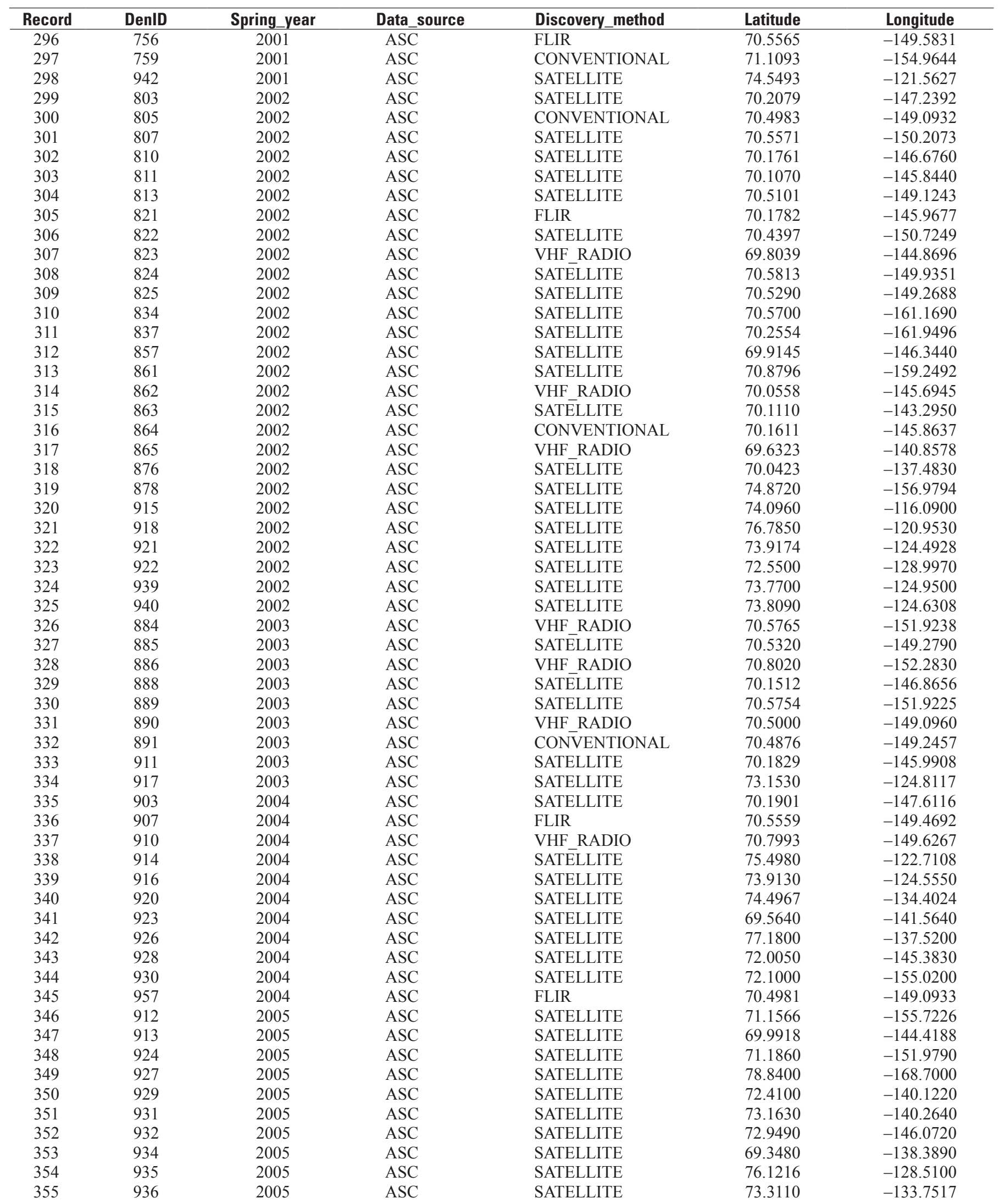


Appendix 1. Records of polar bear maternal dens collected by the USGS, Alaska Science Center-Continued

[See appendix 2 for a definition of Data_source and Discovery_method codes]

\begin{tabular}{|c|c|c|c|c|c|c|}
\hline Record & DenID & Spring_year & Data_source & Discovery_method & Latitude & Longitude \\
\hline 356 & 937 & 2005 & $\mathrm{ASC}$ & SATELLITE & 71.3670 & -138.3220 \\
\hline 358 & 947 & 2005 & ASC & CONVENTIONAL & 70.1800 & -145.9737 \\
\hline 360 & 949 & 2005 & ASC & CONVENTIONAL & 70.3134 & -147.9887 \\
\hline 361 & 960 & 2005 & ASC & FLIR & 70.4879 & -149.2453 \\
\hline 362 & 961 & 2005 & ASC & FLIR & 70.2114 & -147.2406 \\
\hline 365 & 952 & 2006 & ASC & CONVENTIONAL & 70.4033 & -149.1279 \\
\hline 366 & 954 & 2006 & ASC & REPORT & 70.0580 & -145.5830 \\
\hline 367 & 955 & 2006 & ASC & REPORT & 70.1503 & -145.8755 \\
\hline 368 & 956 & 2006 & ASC & REPORT & 70.1333 & -145.9393 \\
\hline 369 & 965 & 2006 & ASC & FLIR & 70.5562 & -149.4664 \\
\hline 370 & 967 & 2006 & ASC & CONVENTIONAL & 70.5590 & -149.5327 \\
\hline 375 & 973 & 2007 & ASC & FLIR & 70.4988 & -149.0938 \\
\hline 376 & 974 & 2007 & ASC & CONVENTIONAL & 70.4997 & -149.0949 \\
\hline 377 & 975 & 2007 & ASC & SATELLITE & 70.5555 & -149.5779 \\
\hline 378 & 976 & 2007 & MMM & REPORT & 70.3160 & -151.5043 \\
\hline 379 & 976 & 2007 & MMM & REPORT & 70.3160 & -151.5043 \\
\hline 380 & 978 & 2009 & ASC & VHF_RADIO & 70.1865 & -146.0127 \\
\hline 381 & 979 & 2009 & ASC & VHF_RADIO & 70.3089 & -148.1508 \\
\hline 382 & 980 & 2009 & ASC & VHF_RADIO & 70.5299 & -149.2692 \\
\hline 383 & 981 & 2009 & ASC & VHF_RADIO & 70.5561 & -149.5746 \\
\hline 384 & 982 & 2009 & ASC & VHF_RADIO & 70.8568 & -154.9792 \\
\hline 385 & 983 & 2009 & ASC & VHF_RADIO & 69.1911 & -138.2509 \\
\hline 386 & 984 & 2009 & ASC & VHF_RADIO & 68.8873 & -137.0253 \\
\hline
\end{tabular}




\section{Appendix 2. Definition of Data-source and Discovery method Codes Used in Appendix 1.}

\begin{tabular}{ll}
\hline & \multicolumn{1}{c}{ Data_source } \\
\hline ADFG & Alaska Department of Fish and Game \\
ASC & Alaska Science Center \\
INDUSTRY & Petroleum and related industry personnel \\
LOCAL & Residents of coastal villages and homesteads \\
MMM & US Fish and Wildlife Service, Marine Mammals Management \\
\hline \multicolumn{1}{c}{ Discovery_method } \\
\hline CONVENTIONAL & Encountered during other ASC polar bear field research efforts \\
FLIR & Encountered with Forward-looking Infrared \\
REPORT & Reported to ASC from other individuals or agencies \\
SATELLITE & Encountered through satellite telemetry \\
VHF_RADIO & Encountered through VHF telemetry \\
\hline
\end{tabular}


Publishing support provided by the U.S. Geological Survey

Publishing Network, Tacoma Publishing Service Center

For more information concerning the research in this report, contact the Director, Alaska Science Center

U.S. Geological Survey

4210 University Drive

Anchorage, Alaska 99508

http://alaska.usgs.gov 
